\title{
Effect of planting date on growth and grain yield of fonio millet (Digitaria exilis Stapf) in the Southeast of Senegal
}

\author{
Moustapha GUEYE ${ }^{1 *}$, Ghislain KANFANY ${ }^{2,3}$, Amadou FOFANA ${ }^{2}$, Mamadou GUEYE ${ }^{4}$, \\ Kandioura NOBA ${ }^{5}$ and John Hamman GROVE ${ }^{6}$ \\ ${ }^{1}$ Centre de Recherches Zootechniques de Kolda, Institut Sénégalais de Recherches Agricoles, \\ ISRA/CRZ Kolda, BP 53 Kolda, Sénégal. \\ ${ }^{2}$ Centre National de Recherches Agronomiques de Bambey, Institut Sénégalais de Recherches Agricoles, \\ ISRA/CNRA, BP 211 Bambey, Sénégal. \\ ${ }^{3}$ West Africa Center for Crop Improvement, University of Ghana, PMB 30, Accra, Ghana. \\ ${ }^{4}$ Académie Nationale des Sciences et Techniques du Sénégal, BP 4344 Dakar RP, Dakar, Sénégal. \\ ${ }^{5}$ Faculté des Sciences et Techniques, Université Cheikh Anta Diop de Dakar, BP 5005 Fann-Dakar, Sénégal. \\ ${ }^{6}$ Department of Plant and Soil Sciences, University of Kentucky, Lexington, KY 40546-0091, USA. \\ *Correspondingauthor,E-mail: taffaguey@yahoo.fr; moustapha.gueye@isra.sn;Tel: (+221) 776175527
}

\begin{abstract}
A field experiment was carried out during the rainy cropping seasons of 2010 and 2011 in Southeastern Senegal. The study aimed at investigating the effects of sowing dates on plant growth and grain yield of fonio millet (Digitaria exilis Stapf). Seven planting times (from early July to mid August with 7-day interval) were laid out in a randomized complete block design. In general, plant growth and grain yield were significantly better for the early July sowing dates compared to other sowing dates. However, tillering capacity and grain size were not influenced by the sowing date. Highest grain yields were obtained on 15-July planting date with an average of $1,111 \mathrm{~kg} \mathrm{ha}^{-1}$ in 2010 and $1,269 \mathrm{~kg} \mathrm{ha}^{-1}$ in 2011. Compared to this planting date, the delay in sowing reduced grain yield by $50 \%$ in 2010 and $87 \%$ in 2011 . Detrimental high rains to seedling vigor, decreasing sunshine during the plant growth, and rain deficit during the reproductive phase were among the main limiting factors for late sowings. Hence, the first fortnight of July could be recommended as optimal sowing period for early maturing cultivars of fonio in Southeastern Senegal.
\end{abstract}

(C) 2015 International Formulae Group. All rights reserved.

Key words: Fonio, Digitaria exilis, sowing date, growth, yield, Senegal.

\section{INTRODUCTION}

Fonio millet (Digitaria exilis Stapf) is a cereal crop mainly grown in the southern and southeastern provinces of Senegal (Lo, 2003; USAID, 2008; Cruz et al., 2011). It plays an important role as a complementary staple food in rural areas (Diedhiou, 2008; Vall et al., 2011). In addition, more recently, fonio by- products, like husked grains and parboiled grains, are being used for income generation for small scale farmers and women groups in these areas of the country. Unfortunately, grain yields are low with an average of less than $600 \mathrm{~kg} \mathrm{ha}^{-1}$ (Diedhiou, 2008; ANSD, 2010) and generally farmers failed in marketing the production surplus (USAID, 
2008; Niang-Seydi, 2010). Recent field surveys revealed that farmers prefer planting the early or the intermediate maturing landraces instead of the late maturing ones (Diedhiou, 2008; Kanfany, 2008). The early cultivars help farmers to match the crop growth and development cycle to the duration of actual rainy season (Azam-Ali and Squire, 2002). With climatic changes, the Southern and Southeastern provinces of Senegal have experienced frequent erratic and scarce rainfalls, even though they remain the wettest areas of the country. Under such climate conditions, decision making on whether or not to sow become a real concern to farmers who must cope with a heavy workload over the crop calendar.

In addition, knowledge on the optimal time of sowing is lacking nationwide (USAID, 2008; Fall and Lo, 2009) and little research undertaken in other fonio producing countries mainly focused on germoplasm collections and characterizations, and post harvest technologies improvement (Vodouhe et al., 2003; Vodouhe et al., 2005; Vodouhe and Achigan Dako, 2006). The objective of this study was to investigate the effects of sowing dates on fonio plant growth and grain yield in Southeastern Senegal.

\section{MATERIALS AND METHODS Experimental sites}

Field trials were carried out at two sites in Southeastern Senegal during the rainy seasons of 2010 and 2011. The sites were Bandafassi $\left(12^{\circ} 32^{\prime} \mathrm{N}, 12^{\circ} 18^{\prime} \mathrm{W}, 215 \mathrm{~m}\right.$ above sea level) and Sinthiou Maleme (13 $49^{\prime} \mathrm{N}$, $13^{\circ} 55^{\prime} \mathrm{W}, 6 \mathrm{~m}$ above sea level). Bandafassi is located in Kedougou province and Sinthiou Maleme is located in Tambacounda province (Figure 1). In this part of the country, the rainy season starts between mid May and June, and ends in October, with a unimodal pattern where August and September are the rainiest months. The trends of the main agrometeorological parameters are shown in Figures 2 and 3. The long-term rainfall (19712000) averages are $1085 \mathrm{~mm}$ at Bandafassi and $677 \mathrm{~mm}$ at Sinthiou Maleme. For both sites, air temperature is lower whereas air humidity is higher during the rainy season. Soil analyses show that the soils of both sites were acidic with low organic matter and low cation exchange capacity (Table 1). The soil in Bandafassi was sandy to clayey with small gravels in the topsoil layer and it was sandy to loamy in Sinthiou Maleme.

\section{Experimental design}

Seven (7) sowing dates were assigned in a randomized complete block design, with 4 and 5 replicates in 2010 and 2011, respectively. The first sowing dates started on July $1^{\text {st }}$ in 2010 and on July $8^{\text {th }}$ in 2011 and the following sowing dates were at a 7-day interval (Table 2).

\section{Crop management}

The experiment was carried out during the rainy season, from July to October in both years. Prior to sowing, plots were ploughed, manually weeded, and fertilized with NPK complex $\left(15 \% \mathrm{~N}, 15 \% \mathrm{P}_{2} \mathrm{O}_{5}\right.$ and $\left.15 \% \mathrm{~K}_{2} \mathrm{O}\right)$ at a rate of $100 \mathrm{~kg} \mathrm{ha}^{-1}$. Seeds of the early maturing landrace of fonio known as 'Momo' (Diedhiou, 2008; Kanfany, 2008) were broadcasted in each plot at a rate of $30 \mathrm{~kg} \mathrm{ha}^{-1}$ as recommended by Kanfany and Gueye (2011). The weeding and insecticidal spraying against sucking insects and leaf worms were done when needed during each growing season. The plots were protected against domestic animals and birds from grain setting to harvest period. In 2010, all the plots were normally harvested but in 2011 the first sowing date began on July $8^{\text {th }}$, due to late onset of rainy season and dry spell; whereas the last two sowing dates were not harvested, due to poor plant growth and drought during grain filling. For each year, harvest time was done in agreement with the findings of Bakare (2005).

\section{Data collection}

Monthly air temperature, relative humidity, sunshine and long-term rainfall (1971-2000) data were collected at the Agence Nationale de Météorologie du Sénégal 
(ANAMS) and from the Centre National de Recherches Agronomiques de Bambey (CNRA). The daily rainfall was recorded by means of rain gauge placed next to experimental sites.

The plant growth parameters (plant population, plant height, and number of tillers per plant) were assessed in both years. The phenology data (date to $50 \%$ heading, date to $50 \%$ flowering, and date to $50 \%$ grain maturity) were only evaluated in 2010 . The plant population was estimated in 3 small squares measuring $0.5 \mathrm{~m}$ by $0.5 \mathrm{~m}$ randomly taken and delimited in each plot. Plant height and number of tillers per plant were recorded on ten randomly selected plants per plot. The phenology data was only assessed in one replicate due to its high demand in time and labor for the recording.
At maturity, plant stems were cut using sickles at the closest ground possible and sundried for 30 days prior to weighing. Plant aerial biomass weight and grain yield were recorded for each plot in both years. Three 1000 -grain samples were weighed by using a precision balance.

\section{Statistical analyses}

All data were subject to analyses of variance (ANOVA), except the phenological parameters. Mean separations were performed using Least Significant Difference Test if the $F$-test for treatment effects were significant (P $\leq 0.05$ ) according to Gomez and Gomez (1984). These statistical analyses were performed using GenStat Discovery Edition 4 (VSN International Ltd, United Kingdom).

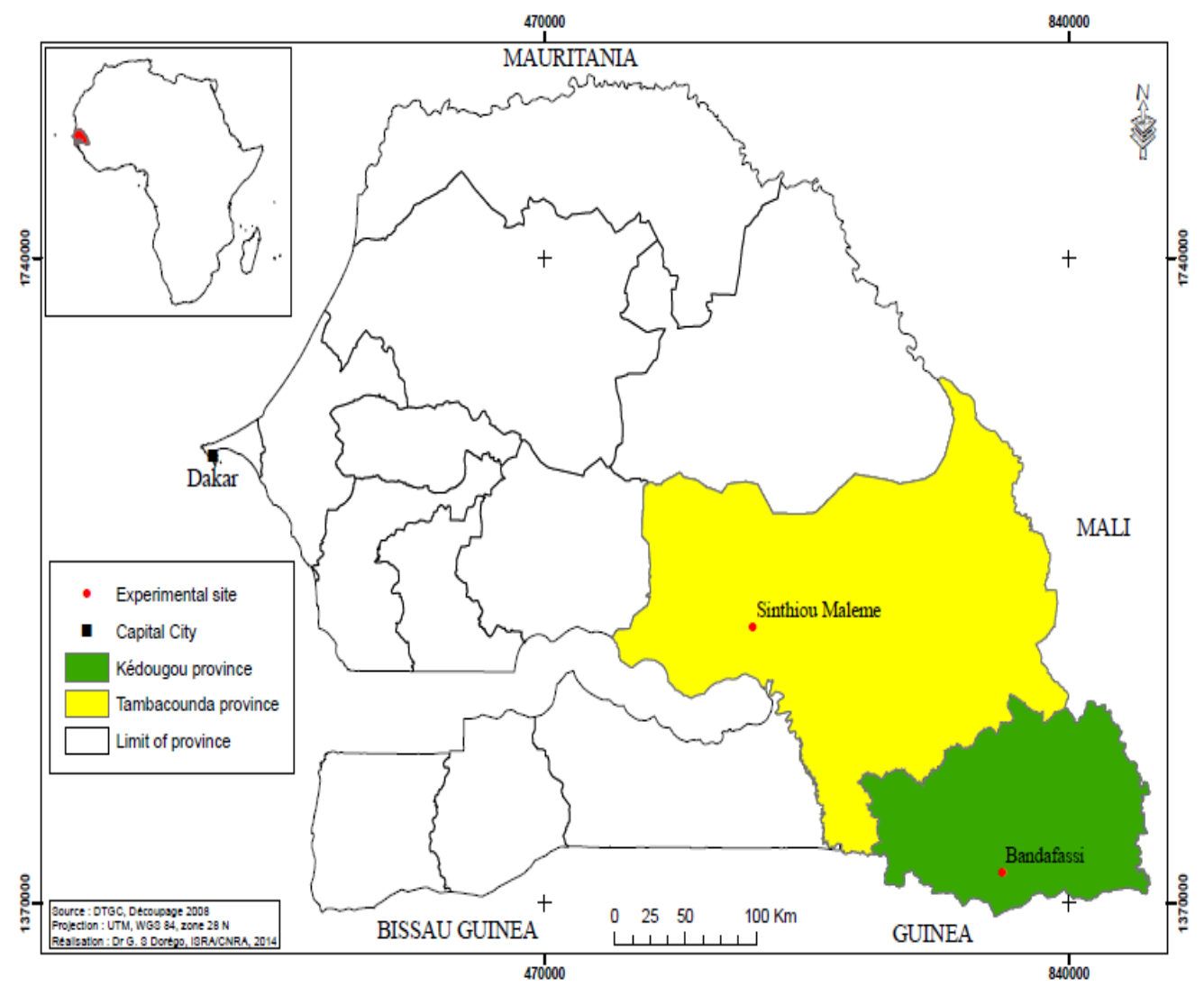

Figure 1: Localisation of the experimental sites in Southeastern Senegal. Courtesy from Dr Seraphin Dorego (CNRA Bambey). 


\section{RESULTS}

\section{Seasonal conditions}

Air temperature and sunshine are shown in Figure 2 for years 2010 and 2011. During the rainy season of 2010, from May to October, the monthly minimum temperature ranged between 21.5 and $27.1{ }^{\circ} \mathrm{C}$ and the maximum between 31.0 and $39.4{ }^{\circ} \mathrm{C}$. The minimum temperature ranged between 21.8 and $26.1{ }^{\circ} \mathrm{C}$ and the maximum between 32.4 and $41.0{ }^{\circ} \mathrm{C}$, during the 2011 rainy season. The monthly duration of the sunshine averaged between 5.3 and 7.2 hours per day for 2010 and between 6.0 and 8.9 hours per day for 2011.

Higher air humidity was observed from May to October (Figure 3). Its minimum and maximum values ranged $38-66 \%$ and $91-98 \%$ in 2010, respectively; whereas they ranged 23$64 \%$ and $56-95 \%$ in 2011 , respectively.

The rainfall for 2010 and 2011 were $1321 \mathrm{~mm}$ for 89 rainy days, and $784 \mathrm{~mm}$ in 45 rainy days, respectively. Both years were considered to have normal rainy season compared to the long-term rainfall from 1971 to 2000 at all sites (Figure 3). However, the rainy season globally was wetter and welldistributed in 2010 while the effective rain started later and ceased earlier in 2011. The early planting dates received more rain compared to the late plantings that had less rainfall during the entire growing season, but more heavy rains during their growth stage for each sowing date (Table 3 ).

\section{Characteristics of plant growth}

For both years, the planting date influenced fonio millet plant population, its vigor and phenology. The early sowing dates generally resulted in better plant growth characteristics (Figures 4 and 5). In 2011, plant population averaged 1029, 661, 530, 275 , and 551 plants $\mathrm{m}^{-2}$ for respectively, the following sowing dates: July $8^{\text {th }}, 15^{\text {th }}, 22^{\text {nd }}$ and $29^{\text {th }}$, and August $5^{\text {th }}$. Days to heading, days to flowering and plant maturity were slightly shortened with late plantings in 2010 (Data were not recorded in 2011). At maturity, as shown in Figure 5, the tallest plants were observed with sowing dates up to July $22^{\text {nd }}$ whereas the shortest plants were observed when sowing dates placed at the end of July and in August $(\mathrm{P}<0.001)$. The number of tillers per plant ranged from 2.6 to 4.4 in 2010 and from 3.7 to 4.5 in 2011 (Figure 5); but this number of tillers was not statistically influenced by the delayed sowing in both years.

\section{Aerial biomass and grain production}

Table 4 shows that sowing date significantly affected plant aerial biomass ( $\mathrm{P}<$ 0.05 in 2010 and $P<0.01$ in 2011) and grain yield ( $\mathrm{P}<0.001$ for both years). Highest aerial biomass and grain yield were obtained with the July $15^{\text {th }}$ sowing date. Sowing before and after this date led to a reduction in biomass and grain yield. Sowing after July $15^{\text {th }}$ reduced aerial biomass and grain yield by $23 \%$ and $50 \%$ in 2010 , respectively, whereas these reductions were respectively $54 \%$ and $87 \%$ in 2011 . The 1000 -grain weight ranged between 0.63 and $0.66 \mathrm{~g}$ in 2010 and from 0.50 to $0.60 \mathrm{~g}$ in 2011 (Table 4). Grain size was higher in 2010 compared to 2011, but was not affected by late planting dates for both years. 


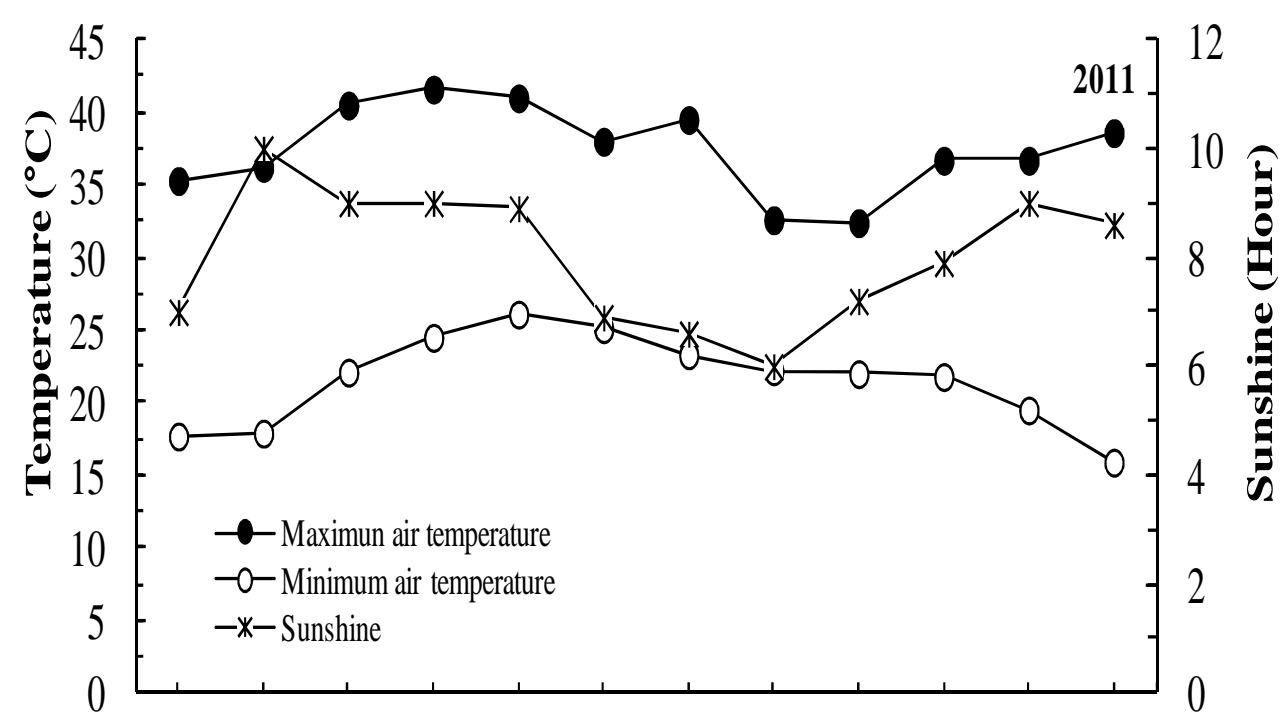

Jan Feb Mar Apr May Jun Jul Aug Sep Oct Nov Dec

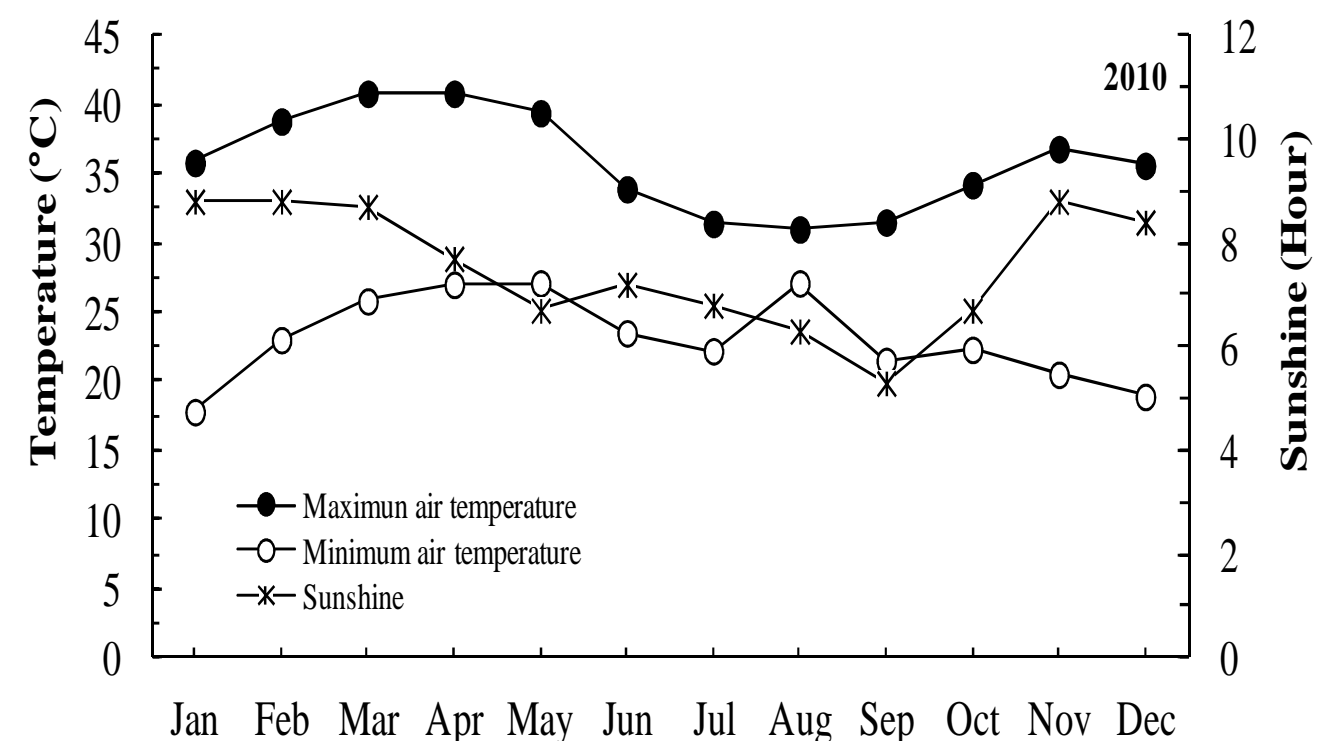

Figure 2: Air temperature and sunhine in Southeastern Senegal in 2010 and 2011. 

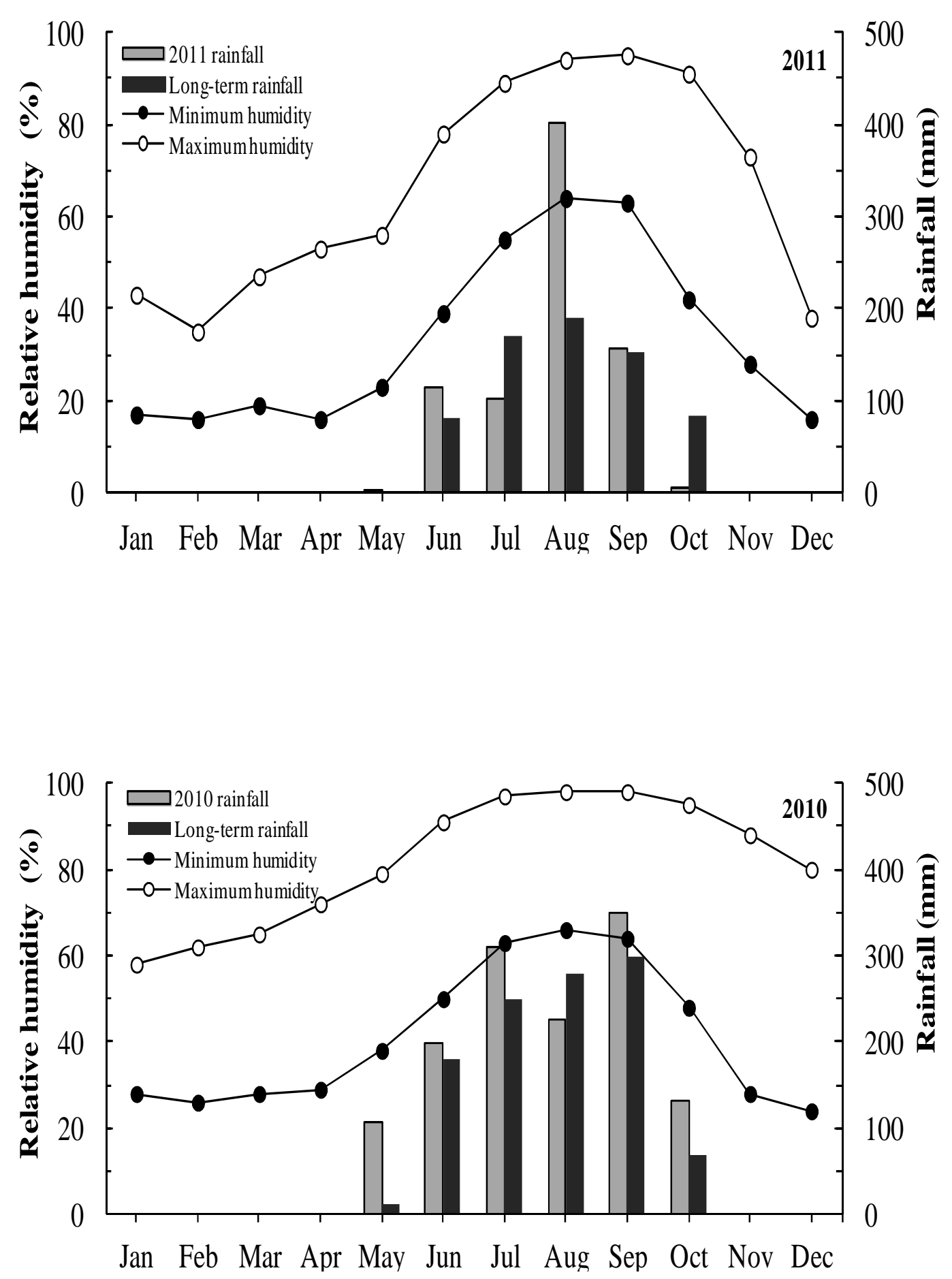

Figure 3: Relative humidity and rainfall in Southeastern Senegal in 2010 and 2011. 


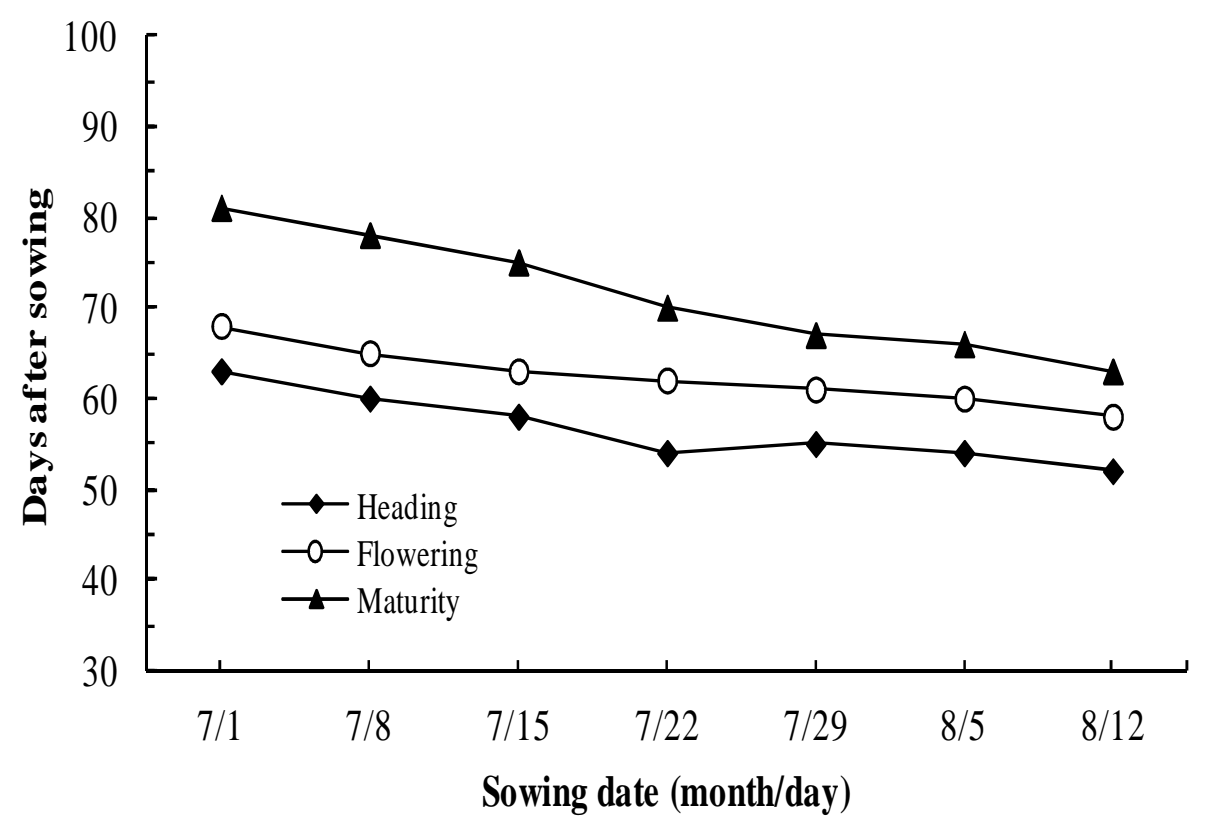

Figure 4: Effects of sowing date on plant phenological stages in fonio in 2010.

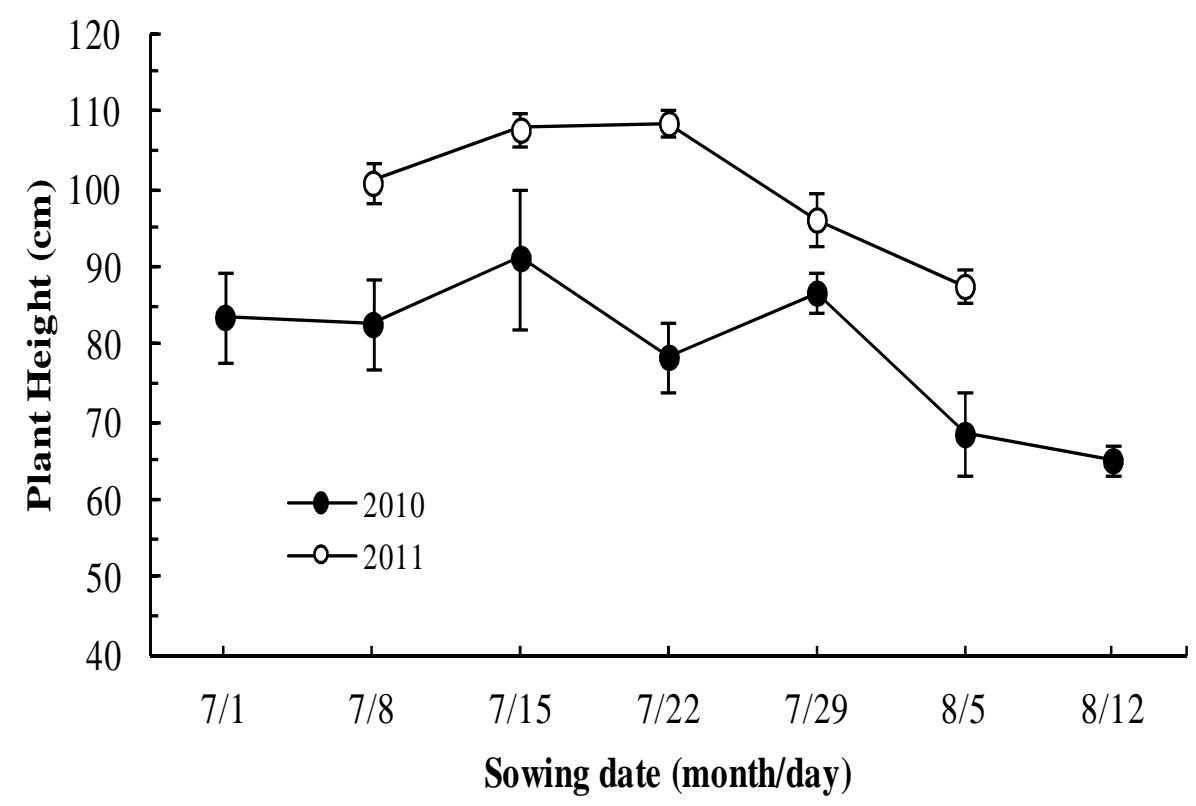




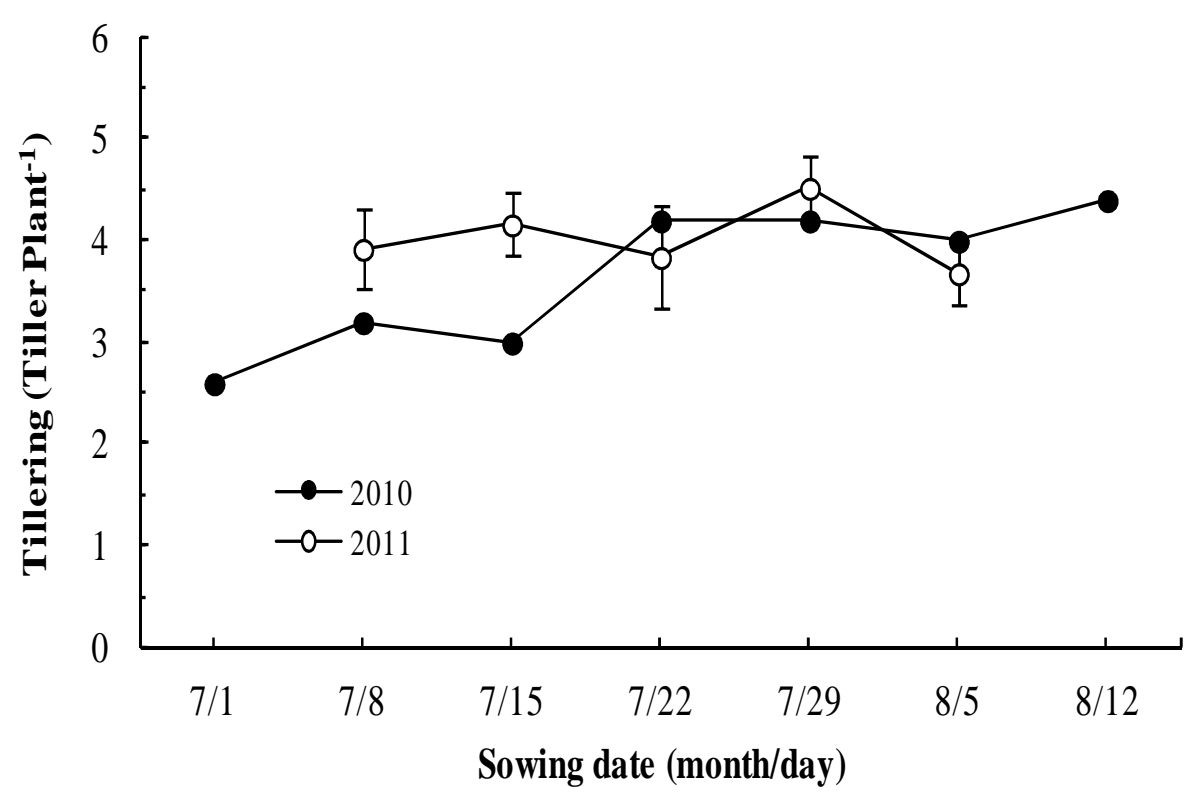

Figure 5: Effects of sowing date on plant height and tillering in fonio in 2010 and 2011. Bars indicate standard error of mean (values from 10 randomly plants for each measure).

Table 1: Characteristics of soils at experimental sites.

\begin{tabular}{lccccccc}
\hline Sites & $\begin{array}{c}\text { Clay } \\
(\boldsymbol{\%})\end{array}$ & $\begin{array}{c}\text { Silt } \\
(\boldsymbol{\%})\end{array}$ & $\begin{array}{c}\text { Sand } \\
(\boldsymbol{\%})\end{array}$ & $\mathbf{p H}$ water & $\begin{array}{c}\text { Organic } \\
\text { matter }(\boldsymbol{\%})\end{array}$ & $\begin{array}{c}\text { Available P } \\
\left(\mathbf{m g ~ k g}^{-\mathbf{1}}\right)\end{array}$ & $\begin{array}{c}\text { CEC } \\
\left(\mathbf{c m o l ~}^{-\mathbf{1}}\right)\end{array}$ \\
\hline Bandafassi & $11,3 \pm 2,1$ & $8,5 \pm 0,3$ & $80,1 \pm 2,4$ & $5,8 \pm 0,1$ & $3,9 \pm 0,2$ & $24,1 \pm 4,2$ & $9,7 \pm 1,0$ \\
Sinthiou Maleme & $5,7 \pm 1,5$ & $3,5 \pm 0,6$ & $90,8 \pm 1,6$ & $5,8 \pm 0,0$ & $3,7 \pm 0,6$ & $22,0 \pm 1,9$ & $7,6 \pm 1,0$ \\
\hline
\end{tabular}

$\mathrm{P}$ (Phosphorus), CEC (Cation Exchange Capacity). Depth of samples was 0-40 $\mathrm{cm}$ and soil samples were taken before planting; In each column, values indicate mean \pm standard error of mean $(n=$ six composite soil samples $)$.

Table 2: Planting dates tested in 2010 and 2011.

\begin{tabular}{lcc}
\hline & \multicolumn{2}{c}{ Planting date } \\
\cline { 2 - 3 } & $\mathbf{2 0 1 0}$ & $\mathbf{2 0 1 1}$ \\
\hline Date 1 & July $1^{\text {st }}$ & July $8^{\text {th }}$ \\
Date 2 & July $8^{\text {th }}$ & July $15^{\text {th }}$ \\
Date 3 & July $15^{\text {th }}$ & July $22^{\text {nd }}$ \\
Date 4 & July $22^{\text {nd }}$ & July $28^{\text {th }}$ \\
Date 5 & July $28^{\text {th }}$ & August $5^{\text {th }}$ \\
Date 6 & August $5^{\text {th }}$ & August $12^{\text {th }}$ \\
Date 7 & August $12^{\text {th }}$ & August $19^{\text {th }}$ \\
\hline In 2011, due to late rain establishment, sowing started on July 8 and ended on August 19.
\end{tabular}


M. GUEYE et al. / Int. J. Biol. Chem. Sci. 9(2): 581-592, 2015

Table 3: Rainfall and rainy days for each sowing date in 2010 and 2011.

\begin{tabular}{|c|c|c|c|c|c|c|}
\hline \multirow{3}{*}{$\begin{array}{l}\text { Sowing date } \\
\text { (month/day) }\end{array}$} & \multicolumn{6}{|c|}{ Rainfall and rainy days from sowing to harvesting } \\
\hline & \multicolumn{3}{|c|}{2010} & \multicolumn{3}{|c|}{2011} \\
\hline & Rainfall (mm) & RD (day) & RD $\geq 10$ mm (day) & Rainfall (mm) & RD (day) & $\mathrm{RD} \geq 10 \mathrm{~mm}($ day $)$ \\
\hline $7 / 1$ & 897 & 62 & 33 & na & na & na \\
\hline $7 / 8$ & 876 & 61 & 32 & 636 & 34 & 17 \\
\hline $7 / 15$ & 817 & 56 & 30 & 613 & 33 & 16 \\
\hline $7 / 22$ & 724 & 59 & 26 & 591 & 32 & 16 \\
\hline $7 / 29$ & 741 & 57 & 28 & 566 & 31 & 15 \\
\hline $8 / 5$ & 696 & 53 & 27 & 499 & 28 & 14 \\
\hline $8 / 12$ & 671 & 48 & 26 & na & na & na \\
\hline
\end{tabular}

$\mathrm{RD}$ (rainy days), $\mathrm{RD} \geq 10 \mathrm{~mm}$ (rainy days with minimum of $10 \mathrm{~mm}$ rainfall per day), na (not applicable).

Table 4: Effects of sowing date on plant aerial biomass, grain yield and grain size in fonio in 2010 and 2011.

\begin{tabular}{|c|c|c|c|c|c|c|}
\hline \multirow[b]{2}{*}{ Sowing date (month/day) } & \multicolumn{2}{|c|}{ Aerial Dry Biomass $\left(\mathrm{kg} \mathrm{ha}^{-1}\right)$} & \multicolumn{2}{|c|}{ Grain Yield (kg ha $\left.{ }^{-1}\right)$} & \multicolumn{2}{|c|}{ 1000-Grain Weight $(\mathrm{g})$} \\
\hline & 2010 & 2011 & 2010 & 2011 & 2010 & 2011 \\
\hline $7 / 1$ & $2562 \pm 157^{\mathrm{ab}}$ & $\mathrm{nt}$ & $938 \pm 47^{\text {ab }}$ & $\mathrm{nt}$ & $0,66 \pm 0,02$ & $\mathrm{nt}$ \\
\hline $7 / 8$ & $2375 \pm 125^{a b c}$ & $7050 \pm 823^{a}$ & $988 \pm 89$ ab & $951 \pm 89^{a}$ & $0,66 \pm 0,03$ & $0,60 \pm 0.00$ \\
\hline $7 / 15$ & $2750 \pm 250^{\mathrm{a}}$ & $8850 \pm 967^{\mathrm{a}}$ & $1111 \pm 138^{\mathrm{a}}$ & $1269 \pm 163^{\mathrm{a}}$ & $0,63 \pm 0,02$ & $0,57 \pm 0.03$ \\
\hline $7 / 22$ & $1875 \pm 298^{c}$ & $6900 \pm 408^{a b}$ & $769 \pm 100^{b c}$ & $461 \pm 78$ & $0,64 \pm 0,02$ & $0,57 \pm 0.03$ \\
\hline $7 / 29$ & $1938 \pm 258^{b c}$ & $4650 \pm 669^{b c}$ & $253 \pm 35$ & $271 \pm 59$ bc & $0,64 \pm 0,03$ & $0,53 \pm 0.03$ \\
\hline $8 / 5$ & $1812 \pm 214^{\mathrm{c}}$ & $4050 \pm 1184^{c}$ & $441 \pm 43$ de & $167 \pm 100^{\mathrm{c}}$ & $0,65 \pm 0,02$ & $0,50 \pm 0.00$ \\
\hline $8 / 12$ & $2000 \pm 323^{b c}$ & nh & $558 \pm 96^{\mathrm{cd}}$ & nh & $0,66 \pm 0,02$ & $\mathrm{nh}$ \\
\hline$F$-Test & $0.040^{*}$ & $0.003^{* * *}$ & $<0.001^{* * *}$ & $<0.001$ & $0,971^{\mathrm{ns}}$ & $0,073^{\mathrm{ns}}$ \\
\hline LSD (0.05) & 656 & 2330 & 248 & 292 & 0,066 & 0,068 \\
\hline
\end{tabular}

Different values in each column represent mean \pm standard error of mean $(n=4$ in 2010, $\mathrm{n}=5$ in 2011).nt: July-1 planting (7/1) was not sown due to late onset of rainy season and dry spell.

nh: the last two sowings (8/12 and 8/19) were not harvested due to drought during grain filling ns: not significant at the 0.05 probability level; $* * * *$ and $* * *=$ significant difference at the $0.05,0.01$, and 0.001 probability levels, respectively. Values followed by the same letter in a column are not significantly different from each other, according to Least Significant Difference Test at 0.05 probability level. 


\section{DISCUSSION}

During the rainy seasons of year 2010 and 2011, weather conditions were normal compared to the long-term rainfall (19712000). However, the rain distribution was better in 2010 than in 2011. Previous reviews pointed out that fonio is grown in tropical areas with low, average or high rainfalls, either in upland or high lands (Vodouhe and Achigan Dako, 2006). In addition, Cruz et al. (2011) reported that fonio is a plant with wide adaptation range and minor effects of climatic or soil conditions. However, poor plant density and slow plant growth observed in late-planted plots are strongly related to high level of rains during post-emergence and the growth stage. Malik and Yadav (2014) reported that better plant vigor was obtained with early sowing. In the case of our study, the number of days having received more than $10 \mathrm{~mm}$ of rain (RD $\geq 10 \mathrm{~mm}$ ) was as important in later plantings as in earlier sowings. Negative effects of high rains on seed emergence and seedling vigor have been observed in buffalograss (Frank et al., 1998).

Plant height was shorter with late plantings in comparison with early ones. Juraimi et al. (2009) reported similar effects with tef grass (Eragrostis tef [Zucc.] Trotter) grown in Ethiopia. Strong reduction in plant height had been previously shown when sowings were delayed on cereal crops (AzamAli and Squire, 2002). Similar findings also have been recently reported in other cultivated crops (Malik and Yadav, 2014; Meena et al., 2015).

Decreases in sunshine due to clouds were more important during the rainy season, particularly for late plantings. This reduction of sunshine could explain the shortening of heading, flowering, and maturing times. These findings are in accordance with those observed with most of local tropical cereal crops grown under short day length (AzamAli and Squire, 2002). This reduction of the length of phenological stages suggests that the landrace used in this study is short photoperiod-sensitive (Aliero and Morakinyo, 2005; Cruz et al., 2011).
In this study, total tillering was not significantly affected by the planting date which is in agreement with the findings of Abou Khalifa (2009) with rice. However, this study revealed that sowing date reduced significantly the number of productive tillers.

Early sowing resulted in better plant growth and higher grain yield compared to late sowing. This result is in agreement with that of warm cereal crops, e.g. corn and sorghum in sub Saharan Africa (Azam-Ali and Squire, 2002). In addition, planting around July $15^{\text {th }}$ led to the highest aerial biomass and grain yield for both years. Before and particularly after this planting date, plant population, plant height, aerial biomass and grain yield are drastically reduced. Similar relationships between sowing date and crop responses have been previously reported on many cereal crops under various conditions (Dokuyucu et al., 2004; Kamara et al., 2009; Aslani and Mehrvar, 2012). These studies showed that delaying planting shortens time to heading or time to flowering and that leads to the reduction of resource capture. This canopy reduction exposes late planted crop to long dry spells or severe drought during the reproductive stage and affects grain setting and filling. Grain size reduction or immature grains increased with late planted cereal crops when drought or high temperature occurred during grain filling (Dokuyucu et al., 2004; Yang and Zhang, 2006; Aslani and Mehrvar, 2012).

\section{Conclusion}

This experiment aimed at investigating the effects of different planting dates on plant growth and grain yield of early maturing landrace of fonio millet. Earlier sowing dates gave highest plant, maximum aerial biomass and highest grain yield. In general, plant growth and grain production were drastically reduced when planting after the $15^{\text {th }}$ of July or in August. These reductions were due to high rainfall, the shortening of day length, and water deficit during the reproductive phase, mainly during grain filling period. For a better development of plants and a high grain yield, 
farmers are invited to sow early maturing landrace of fonio in the first fortnight of July in Southeastern Senegal.

\section{ACKNOWLEDGEMENTS}

This research was a part of the Fonio Project No. 22AP06SS020407 granted by Le Fonds National de Recherches Agricoles et Agro-Alimentaires (FNRAA, Senegal). Additional support was funded by the West Africa Agricultural Productivity Program (WAAPP, Senegal). We thank Jean Christoph Manga, Mamadou Lamine Sonko and Bocar Sagna, field technicians at experimental sites. The corresponding author would like to thank the University of Kentucky (Lexington, KY, USA), for having accepted his scientific visit in 2012.

\section{REFERENCES}

Abou Khalifa AAB. 2009. Physiological evaluation of some hybrid rice varieties under different sowing dates. Australian Journal of Crop Science, 3(3): 178-183.

Aliero AA, Morakinyo JA. 2005. Photoperiodism in Digitaria exilis (Kipp) Stapf accessions. African Journal of Biotechnology, 4(3): 241-243.

ANSD. 2010. Banque de Données des Indicateurs Sociaux du Sénégal (edn 2007-2009), BADIS : Dakar, Sénégal.

Aslani F, Mehrvar MR. 2012. Responses of wheat genotypes as affected by different sowing dates. Asian Journal of Agricultural Sciences, 4: 72-74.

Azam-Ali SN, Squire GR. 2002. Principle of Tropical Agronomy. CABI Publishing: Wallingford, United Kingdom.

Bakare O. 2005. Influence of time of harvest on grain yield of Acha, Digitaria exilis and farmers' perspectives. Int. J. Agric. Rural Dev., 6: 132-135.

Cruz JF, Beavogui F, Drame D. 2011. Le Fonio, une Céréale Africaine. Editions Quae : Versailles, Presses Agronomiques de Gembloux, Gembloux, Belgique ; CTA : Wageningen, Pays-Bas.
Diedhiou CT. 2008. Analyse des systèmes de cultures à base de fonio en Casamance et au Sénégal Oriental. Mémoire d'Ingénieur Agronome, Ecole Nationale Supérieure d'Agriculture de Thiès, Thiès (Sénégal), p. 49.

Dokuyucu T, Akkaya A, Yigitoglu D. 2004. The effect of different sowing dates on growing periods, yield and yield components of some bread wheat (Triticum aestivum L.) cultivars grown in the East-Meditarranean region of Turkey. Journal of Agronomy, 3: 126130.

Fall AA, Lo M. 2009. Etude de référence du Programme sur la productivité agricole au Sénégal dans le cadre du WAAPP. Cas des céréales: mil, sorgho, maïs et fonio. CORAF, PSAOP II, p. 38.

Frank KW, Gaussoin RE, Riordan TP, Miltner ED. 1998. Date of planting effects on seeded turf-type buffalograss. Crop Science, 38: 1210-1213.

Gomez KA, Gomez AA. 1984. Statistical Procedures for Agricultural Research ( $2^{\text {nd }}$ edn). John Wiley \& Sons: New York, NY, USA.

Juraimi AS, Begum M, Sherif AM, Rajan A. 2009. Effects of sowing date and nutsedge removal time on plant growth and yield of tef [Eragrostis tef (Zucc.) Trotter]. African Journal of Biotechnology, 8(22): 6162-6167.

Kamara AY, Ekeleme F, Chikoye D, Omoigui LO. 2009. Planting date and cultivar effects on grain yield in Dryland corn production. Agronomy Journal, 100: 9198.

Kanfany G, Gueye M. 2011. Avantages de respecter la dose de $30 \mathrm{~kg}$ se semences par hectare pour le semis du fonio au Sénégal. Les brochures du FNRAA, n01-2011: 17-18.

Kanfany G. 2008. Diagnostic agronomique du fonio (Digitaria exilis Stapf) dans des parcelles paysannes en Casamance et au Sénégal oriental. Mémoire d'Ingénieur Agronome, Ecole Nationale Supérieure 
d'Agriculture de Thiès, Thiès (Sénégal), p. 45.

Lo M. 2003. La culture du fonio en Casamance : réalités et perspectives. In Actes du Premier Atelier sur la Diversité Génétique du Fonio (Digitaria exilis) en Afrique de l'Ouest, Conakry, Guinée, du 04 au 06 août 1998, Vodouhe SR, Zannou A, Achigan Dako E. (ed). Institut International des Ressources Phytogénétiques (IPGRI), Rome (Italie): 23-25.

Malik RS, Yadav A. 2014. Effect of sowing time and weed management on performance of pigeonpea. Indian Journal of Weed Science, 46(2): 132134.

Meena SS, Mehta RS, Lal G, Sharma YK, Meena RD, Kant K. 2015. Effect of sowing dates and crop geometry on growth and seed yield of dill (Anethum sowa L.). International J. Seed Spices, 5(1): 79-82.

Niang-Seydi MF. 2010. Analyse de la filière fonio en Casamance et au Sénégal Oriental: Situation actuelle et opportunités de développement. Mémoire d'Ingénieur Agronome, Ecole Nationale Supérieure d'Agriculture de Thiès, Thiès (Sénégal), p. 60.

USAID. 2008. Chaîne de Valeur de la Filière Fonio au Sénégal. International Resources Group: Washington D.C., USA.

Vall E, Andrieu N, Beavogui F, Sogodogo D. 2011. Les cultures de soudure comme stratégie de lutte contre l'insécurité alimentaire saisonnière en Afrique de l'Ouest : le cas du fonio (Dgitaria exilis Stapf). Cahiers Agriculture, 20(4): 294300.

Vodouhe SR, Achigan Dako EG. 2006. Digitaria exilis (Kippist) Stapf. [Internet] Record from Protabase. Brink M, Belay G (ed). PROTA (Plant Resources of Tropical Africa), Wageningen (Netherlands). http:// database.prota.org/search.htm>.

(Accessed on May 30, 2012).

Vodouhe SR, Sidibe A, Glele P, Kuta D, Diallo A. 2005. Promoting fonio production in West and Central Africa through germplasm management and improvement of post harvest technology. Final Projet Report. Projet no. 2000.7860.0-001.00. IPGRI and CORAF/WECARD. http://www. underutilized-species.org (Assessed on April 2012).

Vodouhe SR, Zannou A, Achigan Dako E. 2003. Actes du Premier Atelier sur la Diversité Génétique du Fonio (Digitaria exilis) en Afrique de l'Ouest. Conakry, Guinée, du 04 au 06 Août 1998. Institut International des Ressources Phytogénétiques (IPGRI), Rome, Italie.

Yang J, Zhang J. 2006. Grain filling of cereals under soil drying. New Phytologist, 169: 223-236. 